\title{
IAMJ
}

INTERNATIONAL

AYURVEDIC

MEDICAL JOURNAL

\section{A STUDY ON INFLUENCE OF CLASSICAL INDIAN DANCE PRACTICE ON CARDIO - RESPIRATORY WELL BEING}

\author{
Nisha Kumari ${ }^{1}$, M Gautam Shetty ${ }^{2}$ \\ ${ }^{1}$ Professor and Head of the Department, Yenepoya Ayurveda Medical College - Mangalore, Karnataka, India \\ ${ }^{2}$ Professor and head of the Department, Karnataka Ayurveda Medical College - Mangalore, Karnataka, India
}

Corresponding Author: nishaathikary@gmail.com

\section{https://doi.org/10.46607/iamj1208102020}

(Published online: October 2020)

Open Access

(C) International Ayurvedic Medical Journal, India 2020

Article Received: 14/09/2020 - Peer Reviewed: 28/09/2020 - Accepted for Publication: 03/10/2020

\section{(D) Check for updates}

\section{ABSTRACT}

Dance is a Rhythmic form of exercise. It involves slow to intense kinetic footwork, swaying hand gestures and subtle eye - facial expressions. It activates skeletal muscles, stimulates functioning of smooth muscles and enhances the contractility of cardiac muscles. Along with this dance practice also alters breathing mechanism with reference to enhancement of vital capacity. Thus, dancing regularly helps the overall functionality of Cardio - Respiratory system which changes the individual's wellbeing. The following study analyses the mode of action of dancing over the system of the internal body and explains the same with Physical and subjective parameters. Regular dancing helps an individual in betterment of functions of cardiac and respiratory system.

Keywords: Bharathnatyam, Adavu, Samaveda, Ayurveda, Ardha Shakthi, Vital capacity, Endurance

\section{INTRODUCTION}

Samaveda is one among four Vedas describes various forms of music, art and dance. Rigveda being the oldest among the Vedas also has explained different forms of music and dance. Another Veda called Atharva veda contains Ayurveda as one of the contents. Ayurveda is classical text that contains Science, Medicine and Philosophy for all living creatures in the Universe. Therefore, for the well-being and to enhance quality of life 
the concept of music and art is borrowed from $\mathrm{Sa}$ maveda and implemented in Ayurvedic holistic lifestyle for promoting cardiorespiratory health through dancing. The benefits of dancing on internal system is well understood as one presents the features of increased endurance, easy breathing, feeling lightness, good sleep, increase of appetite, fat regulation and feeling cheerfulness.

Need for the study: Sedentary lifestyle, high calorie diet, Stressful mind, sleeplessness, poor physical activity in present days will cause somatic diseases like Obesity, Asthama, Hyperlipidemia, Hypertension. Psychological disorders like Depression, anxiety and Insomnia which may turn person towards narcotic addictions that will in turn damage the internal organs. Apart from medications patients need alteration in lifestyle and inculcate few new practices in their routine. Dance is one such element that has to be included in daily regime along with exercise or dancing alone. It will help to reduce body weight, avoid fat accumulation, activate musculoskeletal system, and also refresh mind as they engage themselves in spending quality time. It can be a good way of distraction to people who suffer from stress and depression.

Materials and Methods: Individuals who are trained or familiar with Indian classical music and dance are selected. The dance form "Bharatnatyam" was chosen to perform. Particular adavus (pattern of beating legs/footsteps) were selected to Particular system. The instructed adavus were practiced by the participants from slow to moderated speed for stipulated time of 30 minutes per day with regular intervals. The practice was continued daily for 30 days. After 30 days the participants were assessed on following subjective parameters.

Physical flexibility; Endurance; Ability to perform and complete; Sense of lightness; Quality of Sleep; Quality of ventilation; Performance quality in other tasks; Cheerfulness

10 volunteers were selected randomly aged between 25 -45 years. They were instructed to perform and practice Thattadavu, Thattu mettadavu, Naatadavu, Thirmana Adavu, Nadai (form of Bharatnatyam steps) in first and second speed. Each adavu is practiced for five minutes.
After performing each adavu one-minute rest was given. Total 30 minutes practice each day was done for 30 days

Observation: Gasping, fatigue and sore calf muscles were present at first week of practice. Out of 10 volunteers 8 could not complete 30 minutes. They stopped after 10 minutes due to exhaustion and poor physical flexibility. The remaining 2 volunteers could complete the practice but after taking longer intervals multiple times in between the practice. During the second week fatigue and sore muscles were decreased but exhaustion continued among 8 volunteers. Two Volunteers could finish the practice taking short intervals in between. During the third week 8 volunteers could complete the practice with longer intervals in between, but they could practice with ease and better flexibility. The remaining two volunteers were able to complete the practice at 30 minutes with advised speed and intervals. During the fourth week all the 10 volunteers were able to perform and complete the Adavu practice with ease and no discomfort. All the volunteers completed the task after completing 30 minutes with regular and prescribed intervals all together at one time. There was minimum gasping, less fatigue, good flexibility and endurance.

1. Physical flexibility: All the 10 volunteers attained required flexibility after completion of 30 days

2. Endurance: After the completion of 30 days apart from dancing volunteers were also able to perform better in their working place as well as could complete domestic work at their homes.

3. Ability to perform and complete: All the 30 volunteers gained their lost physical capacity and attained active throughout the day completing the daily tasks with ease.

4. Sense of lightness: All the 10 volunteers had intense sweating during the practice, they all attained sense of lightness where earlier they had feeling of lethargy and heaviness of the body.

5. Quality of Sleep: All the 10 volunteers had adequate sound sleep and woke up fresh next day. They worked with more clarity and less stress

6. Quality of ventilation: Among the 10 volunteers 2 individuals had bronchial Asthama, they reported 
to have no attacks of Dyspnoea after regular dance practice. This gives a result that dancing enhances vital capacity

7. Performance quality in other tasks: Volunteers remained active in multi-tasking in both physical performance and also those tasks that need brain exercise.

8. Cheerfulness: All the 10 volunteers reported that they had increase in their patience, achieved grace in their face, address their clients with cheerfulness and handle the situation more sensibly rather than getting impulsive.

\section{DISCUSSION}

\section{Effect of dancing in cardiovascular system}

1. Dancing enhances the contractility of heart chambers which increases cardiac output and meets the oxygen and nutrition demand from all other organs

2. Dancing activates blood vessels and valves and thus improves perfusion

3. Dancing increases the speed of blood flow so if any minor obstacles are found in the circulatory tree, that will be cleared

4. Dancing enhances arterial supply and also improves venous return

5. By this mechanism person who practice dance can be prevented from varicose veins, venous hypertension, sore calf muscles and decrease the risk of intra vascular coagulopathy ${ }^{7}$.

6. It regulates blood pressure, prevents stroke, strengthens skeletal muscles by providing more blood.

7. It removes metabolic wastes, bad cholesterol through sweating and controls body weight.

The act of dancing is beyond mere physical movements because dancing is programmed and skilled movement with various kinetics and balancing. It requires motor stimulation and prior neuron preparation to avoid fall to pick up balance. As dancing goes in rhythm of music, the foot tapping requires coordination of musculoskeletal system with nervous system and human intelligence. Lungs extract maximum air from the atmosphere to the raised demand of oxygen, heart pumps in good force with blood vessels to circulate the required oxygen, the muscles give energy to perform this action and the nervous system regulates this entire mechanism. The present article though restricted to cardiorespiratory well-being, but dancing has a focus on holistic mind-body well-being. It may look similar to exercise and cardiovascular fitness, but Exercise is very much related to Brain health, and Cognition, including the ageing process and one of the healthy brain ageing (HBA) strategies to postpone the ravages of Alzheimer's disease.

Dance movements that stretch and expand chest cavity can accommodate more oxygen during inspiration. Dancing enhances motor activity that bring mechanical changes in the muscles. The muscle involved in respiration get greater contractility to fasten the act of respiration. During dancing there is increase in oxygen demand and increased muscle contractility. Thus, when the diaphragm contracts and pulled downwards and at the same time when the chest is expanded there is increased quantity of oxygen entering into lungs.

Conditioning a person's skeletal muscle can gradually increase his/her endurance. There is less chance of developing cognitive disorder if an individual engages in learning new dance movement.

The mechanical action of skeletal muscle and physically working body will increase body temperature. The thermo receptors will carry the impulse to the hypothalamus in the brain to begin sympathetic response to increase heart rate, blood pressure and venous return to cause overall enhancement in cellular perfusion.

Below is the interpretation on probable mode of action of dance on cardiorespiratory system: - 


\section{Probable mode of Action 1: \\ Dancing}

Dancing stimulates motor neurons in the Brain.

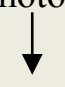

The motor receptors from the skeletal muscles of limbs gets activated during dancing and it reaches brain to stimulate hypothalamus

From the Hypothalamus the sympathetic nerve fibers pass the stimulus to secrete Noradrenalin.

Secretion of Noradrenalin increases the Heart rate

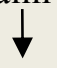

This increases Blood pressure too finally leading to increased Cardiac output

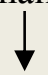

When the Heart ejects more blood, more amount of blood flows to the skeletal muscles which is responsible for reception of more Oxygen and Nutrition to the muscles of Limbs 5 .

Limbs become stronger and this increases a person's endurance.

Probable mode of Action 2:

Dancing causes contraction of calf muscles

It will compress veins and pushes blood upwards for venous return

It prevents retention of blood in calf region

Avoids edema, varicose veins, pain in calf muscles

Probable mode of Action 3

The mechanical action of skeletal muscles during exercise or dancing will cause the body to increase the body temperature ${ }^{6}$. This stimulates

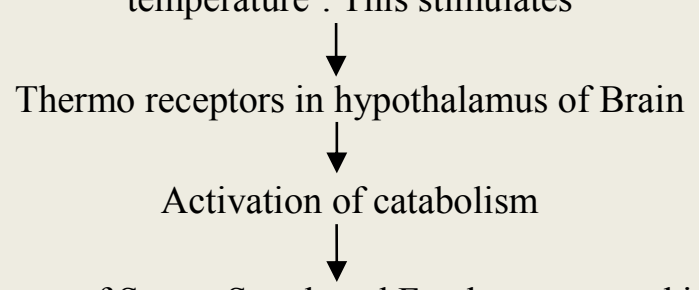

Breaking down of Sugar, Starch and Fat that are stored in the body ${ }^{8}$

Metabolic wastes are excreted through process of sweating

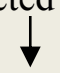

Detoxification and Fat regulation

Removal of bad fat will keep heart healthy. 


\section{According to Ayurveda benefits of Dancing (Nat- yabyasa) to the Heart (Hridaya)}

1. Natyabhyasa stimulates Prana vata (nervous system and respiratory system), and Udana Vata (expiration) to breathe abundant oxygen, and stimulate neural mechanism 1

2. Natyabhyasa helps Vyana vata to enhance motility of maamsa (muscles) of shaka (limbs) for greater contractility.

3. Vyana vata also increases pumping action of heart thus by enhancing circulation (rasa samvahana) so that Prana (oxygen) and Ahara Rasa (nutrition) reach every cell of the body. 2

4. Natyabhyasa enhances Sadhaka pitta present in hridaya to enhance one's emotional quotient. This will enhance concentration, alertness, creative sense, cognition. It augments the mind and improves grasping power. 2

5. Natyabhyasa tones Kapha by decreasing unwanted mucus production and its occlusion in the Chest organs. It Reduces Dushta Meda (bad fat) and prevent them from blocking the heart. Reduction in Kapha causes decrease of Dhamani prathichaya (Atherosclerosis) and thus reducing the risk of Coronary Artery Diseases. 3

6. It decreases the Tamo guna (the inhabitant quality of mind) and drives away dullness, laziness, Lethargy thus by activating the Cardiac activity. 4

7. It gives Harsha (Cheerfulness) to the Manas (mind), where Ayurveda scholars opine that Sthana (site) of mind is Hridaya (heart). Hence one owns well-functioning heart if dancing is practiced regularly. 4

\section{Precautions:}

- Do it after medical guidance and instructions

- Keep room well ventilated and body well hydrated

- Always dance in First Speed to Second speed.

- Take break every five minutes after dancing

- Check that you breathe easy, no gasping, no nausea, no giddiness or blackouts and no chest pain or chest discomfort.

- In Ayurveda we say Ardha Shakthi Vyayama. That is one should workout half of his/her capacity, not beyond that. Now how can you measure that you have done apt workout?

- Swedaha lalate, (sweating over forehead) Shanka, (sweating in temporal region) Manya (sweating over neck) with comfortable breathing, but not gasping, no sense of any discomfort is the perfect number of daily workouts.

\section{CONCLUSION}

Exercise and Physical activeness are essential for good speed of blood circulation. Dancing fulfills the need of exercise and avails the benefit of yoga as well as meditation. The music used for dance, the rhythm of footsteps in the dance enhances mental well-being. It decreases depression and anxiety which reduces cardiac stress. Active circulation prevents blood pooling, block and plaque formation within the blood vessel. Regular dance practice up to an individual's Ardha Shakthi can prevent coronary artery diseases, Obesity, Hyperlipidemia, venous insufficiency and related diseases. It can increase the stretching/elasticity and muscle contractility of Smooth, Skeletal and Cardiac muscles. Blood can get accumulated in unwanted areas like gastrointestinal tract or belly region when a person is in sedentary routine. Dancing can deviate the blood getting unnecessary accumulation in unwanted areas and pour the blood to skeletal muscles. This enhancement in blood supply to the muscles of limbs keeps the skeletal system strong and more durable.

\section{REFERENCES}

1. Sharma R.K. Das B. (trs.) Charaka Samhita Vols. 1- 5. Chowkambha Sanskrit Series Office, Varanasi, India: 2006

2. Acharya Vaidya Jadavaji Trikamaji, Aachrya Narayana Rama. Sutra Sthana Dalhana. 8th edition. 49. Vol. 1. Chaukhamba Orientalia; 2005. Susruta, 'Susruta Samhita' with 'Nibandha Sangrha' commentary by Dallhanacharya; p. 12

3. Agnivesh, Caraka Samhita, Sutrasthan2/30. Ayurveda Deepika Commentary by Cakrapanidutta. Yadavji Trikramji Acharya, editor: Varanasi: Chaukamba Surabharathi Prakashan; 2011.P 26

4. Hemadri - Vagbhatta, Ashtanga Hridaya, Sutrasthana1/17.Sarvangasundara and Ayurveda Rasayan 
Commentary of Arundatta and Hemadri. Bhisagacharya Hari Sadashiva Shastri Paradakara Vaidhya, editor. Varanasi: Chaukamba Surabharathi Prakashan; 2011.p12

5. Betts, J. Gordon (2013). Anatomy \& physiology. pp. 787-846. ISBN 1938168135. Retrieved 11 August 2014.

6. Anderson, RM. The Gross Physiology of the Cardiovascular System (2nd ed., 2012).Chapter 1: Normal Physiology."

7. Hall, Arthur C. Guyton, John E. (2005). Textbook of medical physiology (11th ed.). Philadelphia: W.B. Saunders. p. 106. ISBN 978-0-7216-0240-0.

8. Nisha Kumari, M Gautam Shetty: Biotransformation of Ama in Yakruth - International Ayurveda Medical Journal ISSN; 2320-5091, Volume 7, Issue 6, June2019 pp 916-920

\section{Source of Support: Nil}

\section{Conflict of Interest: None Declared}

How to cite this URL: Nisha Kumari \& M Gautam Shetty: A Study On Influence Of Classical Indian Dance Practice On Cardio - Respiratory Well Being. International Ayurvedic Medical Journal \{online\} 2020 \{cited October, 2020\} Available from: http://www.iamj.in/posts/images/upload/4643 4648.pdf 